\title{
Multiple GnRHs present in a teleost species are encoded by separate genes: analysis of the sbGnRH and cGnRH-II genes from the striped bass, Morone saxatilis
}

\section{M Chow, K E Kight, Y Gothilf, D Alok, J Stubblefield and Y Zohar}

Center of Marine Biotechnology, University of Maryland Biotechnology Institute, Suite 236, 701 East Pratt Street, Baltimore, Maryland 21202, USA

(Requests for offprints should be addressed to Y Zohar)

(M M Chow is now at Hawaii Institute of Marine Biology, University of Hawaii, PO Box 1346 Kane'ohe, Hawaii 96744)

\begin{abstract}
$\mathrm{GnRH}$ is a neuropeptide which plays an essential role in the control of reproductive fitness for all vertebrates. Increasing evidence suggests that multiple forms of GnRH may exist in most vertebrate brains. Southern blot analysis of the three GnRHs known to be present in perciform fish, the seabream (sb)GnRH, the salmon(s) GnRH and the chicken (c) GnRH-II, demonstrates that each is present as a single gene copy in the genome of the striped bass, Morone saxatilis. In order to investigate the physiological consequences of multiple GnRHs in a single vertebrate species, we have isolated and characterized two of the $\mathrm{GnRH}$ genes, those for sbGnRH and cGnRH-II. Computer analysis of $3.5 \mathrm{~kb}$ of sequence upstream of the sbGnRH gene reveals a number of consensus DNA binding sites which implicate steroids, such as estrogen and glucocorticoids, and the steroidogenic
\end{abstract}

transcription factor, $\mathrm{SF}-1$, as being involved in the regulation of sbGnRH gene expression. Sequence analysis of the cGnRH-II gene reveals evidence of multiple promoters. Expression studies using (1) solution hybridization-RNAse protection mapping with several RNA probes directed at various regions of the proGnRH gene, (2) primer extension assays using two specific oligonucleotide primers, and (3) reverse transcription PCR with several oligonucleotide primers on cGnRH-II transcripts demonstrate that the cGnRH-II gene initiates transcription at numerous sites using a TATA-less promoter within the brains of sexually mature striped bass. This study is the first to characterize and compare the promoter structures of two GnRH genes present in a single vertebrate species.

Fournal of Molecular Endocrinology (1998) 21, 277-289

\section{INTRODUCTION}

Gonadotropin releasing hormone $(\mathrm{GnRH})$ is a neuropeptide that plays a pivotal role in the reproduction of all vertebrates. GnRH is synthesized in the hypothalamus, released into the median eminence and transported via the portal vessel, in the case of mammals, or via direct neuronal innervation, in the case of fish, to the pituitary where its primary neurohormonal function is to activate the synthesis and release of gonadotropins. The gonadotropins, in turn, stimulate steroidogenesis and gonadal development. Thus, GnRH represents the first step in a cascade of hormones, all of which participate in the coordination of the complex physiology of reproduction.
Like many other hormones, GnRH was named on the basis of its known function. However, it has become increasingly clear that GnRH has functions in addition to stimulating the release of gonadotropins. GnRH, like many neuropeptides, is expressed in numerous brain locations and may act as a neurotransmitter, neuromodulator, or local hormone (for reviews, see King \& Millar 1991, Sherwood et al. 1994).

Only a relatively few highly specialized neurons synthesize GnRH (Muske 1993), and correspondingly there are only nanogram quantities of $\mathrm{GnRH}$ produced within the brain. For this reason, traditional peptide extraction methods used to isolate and purify $\mathrm{GnRH}$ have historically been extremely difficult. Since the original isolation of 
TABle 1. Amino acid sequences of the ten forms of GnRH identified to date in vertebrate species. Traditionally each form has been named for the species in which it was first identified

\begin{tabular}{|c|c|c|c|c|c|c|c|c|c|c|}
\hline & 1 & 2 & 3 & 4 & 5 & 6 & 7 & 8 & 9 & 10 \\
\hline Mammalian & pGlu & His & Trp & Ser & Tyr & Gly & Leu & Arg & Pro & Gly- $\mathrm{NH}_{2}$ \\
\hline Chicken-I & pGlu & $\mathrm{His}$ & Trp & Ser & Tyr & Gly & Leu & Gln & Pro & Gly-NH \\
\hline Seabream & pGlu & His & Trp & Ser & Tyr & Gly & Leu & Ser & Pro & Gly- $\mathrm{NH}_{2}$ \\
\hline Salmon & pGlu & $\mathrm{His}$ & Trp & Ser & Tyr & Gly & Trp & Leu & Pro & Gly-NH \\
\hline Chicken-II & pGlu & His & Trp & Ser & His & Gly & Trp & Tyr & Pro & Gly-NH \\
\hline Dogfish & pGlu & His & Trp & Ser & His & Gly & Trp & Leu & Pro & Gly- $\mathrm{NH}_{2}$ \\
\hline Guinea pig & pGlu & Tyr & Trp & Ser & Tyr & Gly & Val & Arg & Pro & Gly- $\mathrm{NH}_{2}$ \\
\hline
\end{tabular}

the GnRH peptide (Amos et al. 1971, Matsuo et al. 1971), this approach has identified ten distinct forms of $\mathrm{GnRH}$ in every vertebrate phylum investigated, ranging from primitive fish and amphibians, to more recently evolved teleosts, birds and mammals (Table 1).

Previously, two forms of GnRH were known to exist within an individual vertebrate brain: a reproductively relevant form which is species specific and the widespread chicken (c)GnRH-II form whose function is not yet fully understood. Teleost fish of the order Perciformes are the first group of vertebrates in which three distinct forms of GnRH, salmon (s)GnRH, seabream (sb)GnRH and cGnRH-II have been conclusively demonstrated to coexist within a single brain, as shown first in the gilthead seabream, Sparus aurata (Powell et al. 1994). Subsequently the presence of three distinct forms of GnRH was confirmed in other perciform species (African cichlid (White et al. 1995) and striped bass (Gothilf et al. 1996a), tilapia (Weber et al. 1997), red seabream (Okuzawa et al. 1997) and sea bass (M M Chow, M Carillo, S Zanuy \& Y Zohar, unpublished observations)). The physiological consequences of three forms of $\mathrm{GnRH}$ within a single vertebrate species and the possible relevance of each form to reproduction are not yet known.

Each of the three forms of GnRH has a restricted pattern of regional expression in the brain (White et al. 1995, Gothilf et al. 1996b) and appears to be regulated by hormones and environmental cues (Francis et al. 1993, Gothilf et al. 1997). These characteristics make the $\mathrm{GnRH}$ gene family an attractive model to study gene regulation.

We are interested in understanding the functional significance of GnRH multiplicity within a single vertebrate species. In this study, we have chosen a teleost fish, the striped bass, Morone saxatilis, to investigate how multiple GnRHs are differentially regulated. Towards this goal, we have cloned and characterized two of the three $\mathrm{GnRH}$ genes present in the genome of the striped bass, the gene encoding the most recently discovered member of the GnRH family, the sbGnRH, and the cGnRH-II gene. This paper reports the cloning of both $\mathrm{GnRH}$ genes from a vertebrate species and is intended to provide insight into the unique role each form of GnRH may differentially contribute to reproductive competence.

\section{MATERIALS AND METHODS}

\section{Southern blot analysis}

High molecular weight genomic DNA was isolated from the nuclei of male striped bass red blood cells according to the procedure of Cummings \& Thorgaard (1994). DNA $(10 \mu \mathrm{g})$ was digested with either BamHI, HindIII, EcoRI or SacI restriction endonuclease (Promega, Madison, WI, USA) overnight at $37^{\circ} \mathrm{C}$. The restriction digest was separated on a $0 \cdot 8 \%$ agarose electrophoresis gel and transferred to a nylon membrane (MSI Separations, Westborough, MA, USA). Three panels were prepared in this manner and hybridized separately with DNA probes corresponding to either (1) a $180 \mathrm{bp}$ sbGnRH cDNA from gilthead seabream, (2) a $250 \mathrm{bp}$ cGnRH-II cDNA fragment from gilthead seabream, or (3) a $450 \mathrm{bp}$ PCR fragment of the striped bass sGnRH gene. The probes were radiolabeled to high specific activities $\left(1-2 \times 10^{9}\right.$ c.p.m./ $\left./ \mu g\right)$ using a Prime-It-II random priming kit (Stratagene, La Jolla, CA, USA). The filters were hybridized at $65^{\circ} \mathrm{C}$ in $6 \times$ SSC, $5 \times$ Denhardt's solution and $1 \%$ SDS overnight, with a final wash of $0 \cdot 1 \times \mathrm{SSC}, 1 \% \mathrm{SDS}$ at $65^{\circ} \mathrm{C}$. The filters were exposed to X-ray film (Kodak, Rochester, NY, USA) at $-80{ }^{\circ} \mathrm{C}$ for 4 days. 


\section{Construction of the genomic library}

A striped bass genomic library was constructed in Lambda Fix-II vector (Stratagene) according to the manufacturer's instructions. The original library contained $8.5 \times 10^{5} \mathrm{pfu}$ and was amplified on XLI-Blue MRA (P2) selective host cells in 18 petri dishes (50000 pfu per $150 \mathrm{~mm}$ petri dish) and stored as separate fractions.

\section{Initial PCR screening of the striped bass genomic library}

To identify which of the library fractions contained the GnRH gene of interest, an initial PCR screen of the genomic library was carried out using sbGnRH degenerate oligomers sb 1-8 (5'-CGTCGACCA GCAYTGGTCITATG-GIYTNAG-3') and sb 47-55 (5'-GCCTTTCATTC'TGTACATTCTGG GGAC-3'), or cGnRH-II degenerate oligomers c 1-7 (5'-CARCAYTGGTCNCAYGGNTGG-3') and c 30-35 (5'CAYTCICCIGCYTCRCA-3'). Oligos are assigned names which reflect their amino acid positions in the GnRH precursor. An aliquot of each of the 18 library fractions was amplified using the following PCR conditions: denaturing, $94{ }^{\circ} \mathrm{C}$, $1 \mathrm{~min}$; annealing, $50{ }^{\circ} \mathrm{C}, 30 \mathrm{~s}$; extension, $72{ }^{\circ} \mathrm{C}$, $2 \mathrm{~min}$ for a total of 35 cycles. Southern blot analysis, using either the sb 8-15 oligomer $\left(5^{\prime}\right.$-WSNCC TGGIGGIAARMG-3') or a $250 \mathrm{bp}$ cGnRH-II cDNA fragment from gilthead seabream as an internal probe for the sbGnRH and cGnRH-II screenings, respectively, was performed on the resulting PCR products to verify the identity of the bands. Hybridization was carried out overnight in $6 \times \mathrm{SSPE}, \quad 10 \times$ Denhardt's solution, $1 \%$ SDS, $20 \mu \mathrm{g} / \mathrm{ml}$ tRNA and $50 \mu \mathrm{g} / \mathrm{ml}$ denatured calf thymus DNA at either $42{ }^{\circ} \mathrm{C}$ or $60{ }^{\circ} \mathrm{C}$ for the sbGnRH or cGnRH-II probes respectively.

\section{Isolation of the sbGnRH genomic clone}

Of the one genomic library fraction identified to contain the sbGnRH gene, $2.5 \times 10^{5}$ pfu were plated for the primary screen and duplicate filters were lifted from each plate. The filters were hybridized overnight with a ${ }^{32} \mathrm{P}$-labeled sbGnRH cDNA from gilthead seabream (Gothilf et al. 1995 ) at $42{ }^{\circ} \mathrm{C}$ in $50 \%$ formamide, $6 \times \mathrm{SSC}, 5 \times$ Denhardt's solution, $1 \% \mathrm{SDS}, 20 \mu \mathrm{g} / \mathrm{ml}$ tRNA and $50 \mu \mathrm{g} / \mathrm{ml}$ denatured calf thymus DNA and then washed at $60{ }^{\circ} \mathrm{C}$ with $0.5 \times \mathrm{SSC}, 1 \% \mathrm{SDS}$. A single positive plaque was purified to homogeneity after three successive rounds of screening. The purified phage DNA was mapped by restriction enzyme digestion followed by Southern blot analysis using both the random primed gilthead seabream
sbGnRH cDNA and an end-labeled oligomer ( $\mathrm{sb}$ 1-8) as probes. A $6.5 \mathrm{~kb}$ SacI fragment which hybridized with both probes was isolated and cloned into the SacI site of the pBlueScript SK ${ }^{-}$ vector (Stratagene). Sequencing reactions were performed using Ampli-fs Taq DNA polymerase (Perkin Elmer, Madison, WI, USA) and sequenced on an ABI automatic sequencer at the Center of Marine Biotechnology.

\section{Isolation of the cGnRH-II genomic clone}

Of each of two genomic library fractions that tested positive for the cGnRH-II sequence via PCR screening, $8 \times 10^{4}$ total pfu were plated and transferred to nylon filters for subsequent screening. The filters were hybridized overnight with a ${ }^{32} \mathrm{P}$-labeled $250 \mathrm{bp}$ fragment of the cGnRH-II cDNA from gilthead seabream in $6 \times \mathrm{SSC}, 0 \cdot 1 \%$ SDS, $5 \times$ Denhardt's solution and $50 \mathrm{mg} / \mathrm{ml}$ denatured calf thymus DNA at $60{ }^{\circ} \mathrm{C}$ for $16 \mathrm{~h}$. Final wash conditions were $0 \cdot 2 \times \mathrm{SSC}, 0 \cdot 1 \% \mathrm{SDS}$ at $65{ }^{\circ} \mathrm{C}$. Filters were exposed to X-ray film for $36 \mathrm{~h}$. Positively hybridizing plaques were purified to homogeneity using two subsequent rounds of screening. The purified phage DNA was digested with XbaI restriction enzyme, separated via agarose gel electrophoresis, and transferred to nylon membranes for Southern blot analyses. Hybridization and washing conditions were as described above. One positively hybridizing band, a $5 \cdot 2 \mathrm{~kb}$ fragment, was isolated, cloned into the XbaI restriction site of pBlueScript $\mathrm{SK}^{-}$vector and sequenced on an $\mathrm{ABI}$ automatic sequencer in the Biopolymer Lab of the University of Maryland at Baltimore.

\section{Northern blot analysis}

Poly $\left(\mathrm{A}^{+}\right)$mRNA was isolated from pooled striped bass brains of reproductively mature males and females, using a Ribo-Sep RNA isolation kit (Collaborative Biomedical Products, Bedford, MA, USA). Ten micrograms poly $\left(\mathrm{A}^{+}\right)$mRNA were loaded and separated on a denaturing $1.5 \%$ agarose electrophoresis gel alongside RNA molecular weight markers (Gibco BRL, Bethesda, MD, USA). Using a downward capillary Turbo-Blotter (Schleicher and Schuell, Keene, NH, USA), the mRNA was transferred onto nylon membrane in $20 \times$ SSC. $\alpha\left[{ }^{32} \mathrm{P}\right]$ UTP $(800 \mathrm{Ci} / \mathrm{mmol})$ labeled antisense RNA probes for both the striped bass sbGnRH and the cGnRH-II coding regions were transcribed from pBlueScript vectors using $\mathrm{T} 7$ or T3 RNA polymerase to a specific activity of $2 \times 10^{9}$ c.p.m./ug. The single-stranded RNA probes were 
hybridized in $6 \times \mathrm{SSPE}, 5 \times$ Denhardt's solution at $68^{\circ} \mathrm{C}$, washed in $0.5 \times \mathrm{SSC}, 0.1 \% \mathrm{SDS}$ at $68^{\circ} \mathrm{C}$, and exposed to X-ray film for 5 days.

\section{Determination of transcription start sites}

Reverse transcription PCR (RT-PCR) analysis First-strand cDNA was synthesized from $1 \mu \mathrm{g}$ poly $\left(\mathrm{A}^{+}\right)$mRNA in a reaction solution of $50 \mathrm{mM}$ Tris- $\mathrm{HCl}$ (pH 8.3), $40 \mathrm{mM} \mathrm{KCl,} 6 \mathrm{mM} \mathrm{MgCl}_{2}$, $1 \mathrm{mM}$ Dithiothreitol (DTT), 40 units RNasin (Promega), 200 units SuperScript II RNase $\mathrm{H}^{-}$ reverse transcriptase (Gibco BRL), and $50 \mathrm{pmol}$ oligo-dT primer at $50{ }^{\circ} \mathrm{C}$ for $1 \mathrm{~h}$. One-tenth of the resulting cDNA was used as a template in PCR

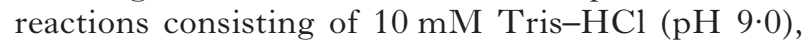
$50 \mathrm{mM} \mathrm{KCl}, 10 \mathrm{mM} \mathrm{MgCl}_{2}, 0 \cdot 1 \%$ Triton X-100, $200 \mu \mathrm{M}$ dNTPs, $2 \cdot 5$ units Taq polymerase (Promega) and $10 \mathrm{pmol}$ each of the forward and reverse primers under the following thermal cycle: $94{ }^{\circ} \mathrm{C}, 1 \mathrm{~min}, 50{ }^{\circ} \mathrm{C}, 1 \mathrm{~min}, 72{ }^{\circ} \mathrm{C}, 2 \mathrm{~min}$ for 40 cycles. The resulting products were separated on agarose electrophoresis gels, transferred to nylon membrane, and probed as described previously.

\section{Primer extension}

Two sequence-specific primers, C2 (5'-TTATCA CTACAGGTGTCCC- $\left.3^{\prime}\right)$ and C3 (5'-TCTCTCT GCTTGTCCTTCAG-3') were end labeled using $\gamma\left[{ }^{32} \mathrm{P}\right]$ ATP (specific activity $6000 \mathrm{Ci} / \mathrm{mmol}$ ). Striped bass brain poly $\left(\mathrm{A}^{+}\right)$mRNA $(30 \mu \mathrm{g})$ was denatured in the presence of each radiolabeled primer at $85^{\circ} \mathrm{C}$ for $5 \mathrm{~min}$ in $50 \mathrm{mM}$ Tris- $\mathrm{HCl}, 75 \mathrm{mM} \mathrm{KCl}$ and $3 \mathrm{mM} \mathrm{MgCl}_{2}$. After the addition of 40 units RNAsin the primers were allowed to anneal to the mRNA template at $52{ }^{\circ} \mathrm{C}$ for $4.5 \mathrm{~h}$. The primer was extended with 4 units SuperScript II RNase $\mathrm{H}^{-}$ reverse transcriptase in the presence of $300 \mathrm{mM}$ dNTPs and $6 \mathrm{mM}$ DTT at $50{ }^{\circ} \mathrm{C}$ for $2.5 \mathrm{~h}$. Each sample was digested with 100 units RNase One (Promega), phenol extracted and precipitated. The primer-extended products were separated on a $6 \%$ denaturing polyacrylamide electrophoresis gel, together with a sequencing reaction generated by the end-labeled $\mathrm{C} 2$ or $\mathrm{C} 3$ primer and the plasmid containing the entire cGnRH-II gene, using the fmol sequencing kit (Promega). The autoradiograph was obtained after exposing the dried gel for 4 days to X-ray film at $-80^{\circ} \mathrm{C}$.

RNase protection assays (RPAs)

Three different probes were used for RPAs. Probe templates were produced by PCR using the isolated cGnRH-II gene and sets of specific primers (see Fig. 3 for details) and subcloned into pBlueScript

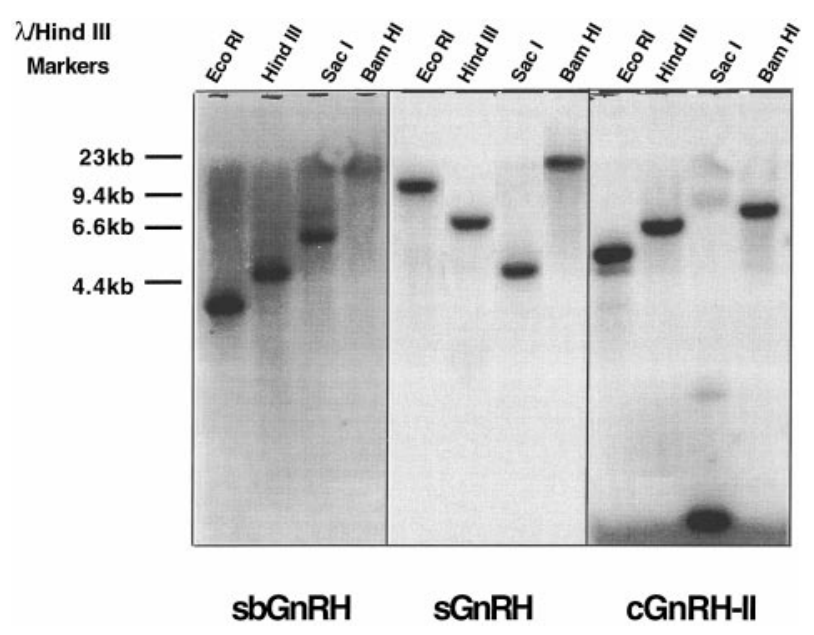

FIGURE 1. Southern blot analysis of striped bass genomic DNA. Each lane contains $10 \mu \mathrm{g}$ striped bass genomic DNA digested with a single restriction enzyme, and each panel was probed with either sbGnRH, sGnRH or cGnRH-II cDNA sequence from gilthead seabream or striped bass, as indicated in Materials and Methods. The hybridization pattern for each $\mathrm{GnRH}$ is consistent with known restriction maps for each gene.

plasmid vectors. The plasmid templates were linearized with the appropriate restriction enzyme and ${ }^{32} \mathrm{P}$-labeled antisense $\mathrm{RNA}$ probes were synthesized using a MaxiScript in vitro transcription kit (Ambion, Austin, TX, USA) according to the manufacturer's instructions. Each RPA was carried out with $30 \mu \mathrm{g}$ poly $\left(\mathrm{A}^{+}\right) \mathrm{RNA}$ using an RPA II kit (Ambion) according to the manufacturer's directions. The resulting protection assay products were separated on a $6 \%$ denaturing polyacrylamide gel and visualized by exposing the dried gel to $\mathrm{X}$-ray film for 4 days.

\section{RESULTS}

\section{Genomic Southern blot analysis}

Genomic Southern blot analysis was performed to detect the presence of each GnRH in the genome of the striped bass (Fig. 1). High molecular weight genomic DNA isolated from the nuclei of striped bass red blood cells was digested with each of four restriction endonucleases: BamHI, EcoRI, HindIII or SacI. With the exception of SacI, each digest produced only a single band when hybridized with striped bass or gilthead seabream GnRH probes. The SacI digest produced multiple fragments $(9 \cdot 0$, 2.3 and $0.5 \mathrm{~kb}$ ) when hybridized to the seabream cGnRH-II cDNA probe. The hybridization patterns generated from all three probes are consistent 
with the restriction maps obtained from DNA sequences of each of the isolated genomic clones and quite distinct when compared with each other. These results clearly indicate that each of the GnRH forms, sbGnRH, sGnRH and cGnRH-II, are present as single copy genes in the striped bass genome.

\section{Isolation and characterization of the striped bass sbGnRH gene}

The initial PCR screen of the individual genomic library fractions using degenerate primers sb 1-8 and sb 47-55 resulted in the identification of only one fraction as positive. A single positive phage clone, containing a $20 \mathrm{~kb}$ insert, was identified and purified to homogeneity after three rounds of screening the phage contained in this fraction. Restriction mapping and Southern blot analysis using either a full length sbGnRH cDNA from gilthead seabream or oligonucleotides corresponding to the $5^{\prime}$ or $3^{\prime}$ end determined that the coding region of the striped bass sbGnRH gene was contained within a $6.5 \mathrm{~kb}$ SacI fragment (Fig. 2A). Sequence analysis revealed that the coding region of the striped bass sbGnRH gene spans $2.0 \mathrm{~kb}$ and consists of four exons and three introns. The organization of the striped bass sbGnRH gene is identical to that reported for all known GnRH genes, suggesting that the overall genomic structure of GnRH genes has been conserved. As shown in Fig. 2A, the GnRH precursor mRNA includes: exon I, which contains the $5^{\prime}$ untranslated region (UTR); exon II, which encodes the signal peptide, the bioactive decapeptide, the enzymatic cleavage site -G-K-R- and a portion of the GnRH associated peptide (GAP); exon III, which encodes the majority of the GAP; and exon IV, which encodes the remainder of the GAP and the 3' UTR. With the exception of exon I, the exon/intron boundaries were predicted by sequence comparisons with a partial striped bass sbGnRH cDNA clone $(\mathrm{C}$ R Steven, Y Gothilf \& Y Zohar, unpublished observations), and corresponding sbGnRH cDNAs available from different species, the gilthead seabream sbGnRH (Gothilf et al. 1995) and the African cichlid sbGnRH cDNA (White et al. 1995) (Table 2).

\section{Determination of the transcription start site of the striped bass sbGnRH gene}

The start site $(+1)$ was predicted by the identification of a canonical TATA box located at bp position -25 . Subsequently, the start site position was established by an RT-PCR technique using
A) sbGnRH gene

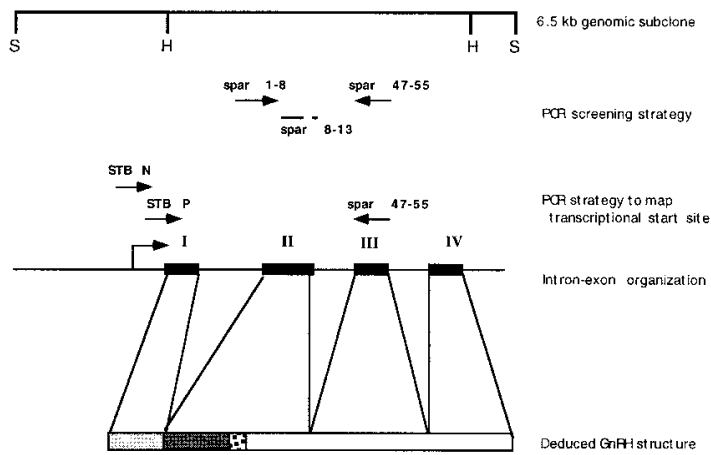

B) cGNFH-II gene
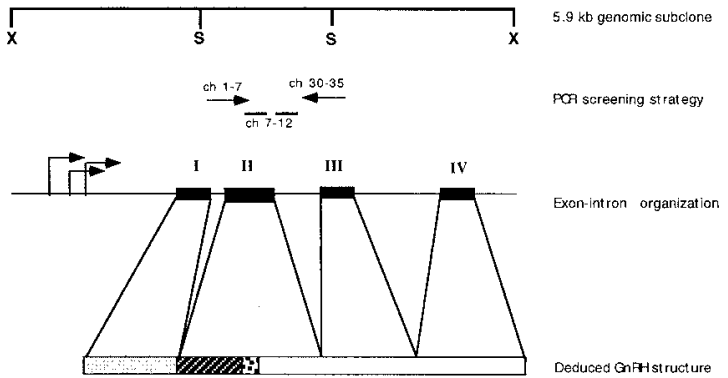

FIGURE 2. Schematic diagrams of (A) sbGnRH and (B) cGnRH-II genes isolated from a striped bass genomic DNA library. The diagrams include restriction maps of both genomic clones isolated from the library, PCR screening strategy used on individual library fractions, RT-PCR approach for mapping the transcriptional start site (sbGnRH gene only), intron/exon organization of the genes and the deduced structure of the $\mathrm{GnRH}$ precursor peptide. Roman numerals indicate exon numbering. Arrows indicate experimentally determined transcription start sites. $\mathrm{S}$ is SacI, H is HindIII and X is Xba I. Exon I consists of the signal peptide, denoted by light grey. Exon II consists of the GnRH

decapeptide, denoted by dark grey (A) and hatching (B), the cleavage site, denoted by the black-on-white stippling, and part of the GAP (no stippling). Exon III and IV both encode for the remainder of the GAP.

poly $\left(\mathrm{A}^{+}\right)$mRNA from the brains of reproductively mature striped bass and primer sb 47-55 located at the end of exon III. Primer STB N, located at -7 to +12 and primer sb $47-55$ gave no observable PCR products or signal when hybridized with oligomers corresponding to internal sequences. In addition, primers STB P2, located at the first exon/intron junction, and STB P3, located entirely within the first intron, each used in combination with primer sb $47-55$, also gave no observable PCR products. However, when primer STB P, located at 
TABLE 2. Comparison (percentage nucleotide sequence identity) of striped bass GnRH exon nucleotide sequences with reported cDNAs from other species

\section{Striped bass sbGnRH exon sequences vs sbGnRH cDNAs from other species}

Striped bass cGnRH-II exon sequences vs cGnRH-II cDNAs from other species

\begin{tabular}{|c|c|c|c|c|c|c|}
\hline Species & $\begin{array}{l}\text { Exon I } \\
5^{\prime} \text { UTR }\end{array}$ & $\begin{array}{l}\text { Signal } \\
\text { peptide }\end{array}$ & Decapeptide & GAP & Exon III & Exon IV \\
\hline Red seabream & 30 & 73 & 93 & 88 & 89 & 83 \\
\hline Cichlid & 40 & 78 & 90 & 88 & 79 & 72 \\
\hline Gilthead seabream & 30 & 67 & 93 & 85 & 75 & 77 \\
\hline Gilthead seabream & 78 & 97 & 97 & 97 & 91 & 83 \\
\hline Cichlid & NA* & 87 & 93 & 85 & 88 & NA* \\
\hline African catfish & $\mathrm{NA}^{*}$ & $\mathrm{NA}^{*}$ & 90 & 68 & 72 & 66 \\
\hline Goldfish & $\mathrm{NA}^{*}$ & 62 & 87 & 59 & 72 & 67 \\
\hline Tree shrew & $\mathrm{NA}^{*}$ & 62 & 87 & 59 & 72 & 67 \\
\hline
\end{tabular}

*NA indicates incomplete or unavailable sequence. Gilthead seabream (Sparus aurata) Gothilf et al. (1995, 1996b); cichlid (Haplochromis burtoni) White et al. (1995); red seabream (Pagrus major) Okuzawa et al. (1994, 1997); African catfish (Clarius gariepinus) Bogerd et al. (1994); goldfish (Carassius aurata) Lin \& Peter (1996) and tree shrew (Tupaia glis belangeri) Kasten et al. (1996).

+28 to +48 within the putative $5^{\prime}$ UTR was used, $\mathrm{STB} \mathrm{P} / \mathrm{sb}$ 47-55 gave a clear band at $250 \mathrm{bp}$ (the correct size predicted by the cDNA) which hybridized to an oligomer corresponding to an internal sequence (data not shown). Because the results were consistent with the predicted start site, no auxiliary experiments, such as primer extension assays, were conducted to further validate this result.

\section{Identification of putative regulatory elements in the striped bass sbGnRH gene}

Of the putative sbGnRH gene promoter, $3.7 \mathrm{~kb}$ has been sequenced and computer analyzed for consensus cis-acting regulatory sequences. A putative cAMP response element (CRE) that matched the published consensus sequence (Roesler et al. 1988) at six of eight bases was identified at -881 to - 874. Additionally, an activator protein 1 (AP-1) binding site with only one base mismatch from the consensus was identified.

A number of DNA elements comprising two or more direct or inverted half-sites have been identified in the $5^{\prime}$ end of the striped bass sbGnRH gene, and may be capable of binding members of the steroid receptor superfamily (see Beato (1989) for reviews on hormonally regulated transcription factors and hormone response elements). A putative glucocorticoid response element (GRE) with $1 \mathrm{bp}$ deviation from the consensus palindromic GRE (GGTACAnnnTGT'TC'T) was found at -2862 to - 2847. An estrogen response element (ERE) palindromic motif, present in the first intron of the sbGnRH gene, contains one perfect ERE half-site and a half-site which displays two mismatches when compared with the consensus palindromic ERE
(AGGTCAnnn'TGACCT). It is worth noting that at least eight ERE half-sites and 16 GRE/ progesterone response element half-sites have been identified in the promoter region matching previously reported sites in other $\mathrm{GnRH}$ gene promoters (Klungland et al. 1993, Coe et al. 1995, Kepa et al. 1996). Of particular interest is the identification of a steroidogenic factor-1 (SF-1) binding site, at -418 to -426 , which is identical to a published SF-1 consensus binding element (Rice et al. 1990).

\section{Isolation and characterization of the striped bass cGnRH-II gene}

A strategy similar to the one which resulted in the isolation of the sbGnRH gene was used to clone the cGnRH-II gene from striped bass (Fig. 2B). Initial PCR screening of the genomic library fractions using primers ch1-7 and ch30-35 identified 2 of the 18 fractions as potentially containing the cGnRH-II gene sequence. After two additional rounds of screening, three individual plaques were isolated and DNA was purified from these phage. Analysis of the DNA from these isolates by restriction mapping indicated that these clones were identical. The phage DNA from one of these isolates was chosen for further subcloning. Digestion with XbaI restriction enzyme yielded three bands that together accounted for the $16 \mathrm{~kb}$ insert region of this recombinant phage. One of these bands, a $5 \cdot 2 \mathrm{~kb}$ fragment, was subsequently found to hybridize with a probe corresponding to the gilthead seabream cGnRH-II cDNA and was therefore isolated for subcloning and sequence analysis.

The architecture of the striped bass cGnRH-II gene is similar to that of all other $\mathrm{GnRH}$ genes 


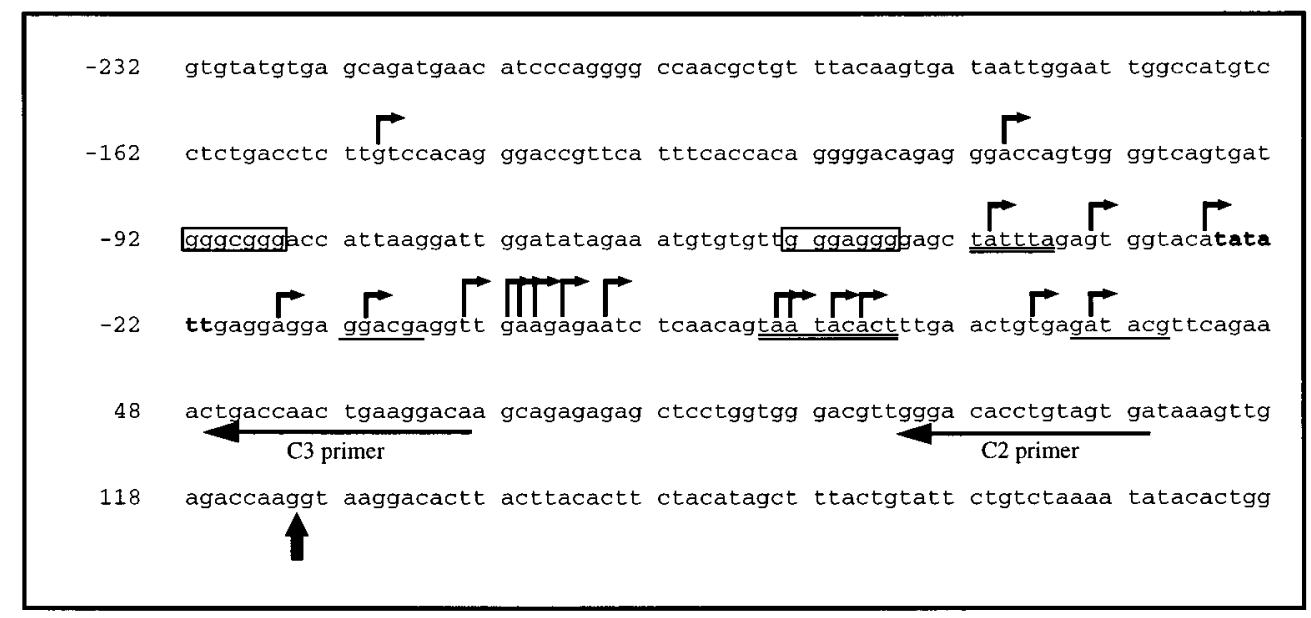

FIGURE 3. Summary of primer extension and RPA results. Multiple start sites (depicted by arrows) were found in the $5^{\prime}$ end of the cGnRH-II gene, and the start sites cluster within a 180 bp window. Tall arrows indicate major transcription start sites. A canonical splice site is designated at +126 by a thick arrow. Candidate SP-1 sites which may be involved in transcriptional activation are boxed and Inr and DPE elements are double and single underlined respectively. Positions of primers used in primer extension assays are also indicated.

characterized thus far, having four exons and three introns (Fig. 2B). With the exception of the 5' UTR encoded by exon $\mathrm{I}$, the remaining exon/intron splice junctions were readily determined based on the high degree of deduced amino acid identity relative to the cGnRH-II cDNA from gilthead seabream (see Table 2). Due to the lack of sequence availability, exon I could not be clearly defined by nucleotide comparison with the $5^{\prime}$ UTRs of cGnRH-II characterized from other species.

\section{Determination of the transcription start site of the striped bass cGnRH-II gene}

The genomic clone included $3.7 \mathrm{~kb}$ of $5^{\prime}$ flanking sequence relative to the translational start site codon of the deduced striped bass cGnRH-II precursor. Based on a $78 \%$ nucleotide sequence identity (Table 2) between the $5^{\prime}$ UTR of the gilthead seabream cGnRH-II cDNA and an upstream portion of the cGnRH-II gene from striped bass, the region located between +30 and +127 was identified as possibly belonging to the $5^{\prime}$ UTR. A canonical intron-exon splice site was found at position +125 . PCR analysis of striped bass brain cDNA using a reverse primer designed to the GAP and forward primers contained within the putative $5^{\prime}$ UTR demonstrated that this region is contained in the primary transcript (data not shown). The absence of a consensus TATA box upstream of the presumptive $5^{\prime}$ UTR and the lack of available full length
cGnRH-II cDNAs from striped bass required that additional analysis be carried out to define the transcriptional unit of the striped bass cGnRH-II gene. Sequence elements that have been shown to be both necessary and sufficient to support transcription from TATA-less promoters were identified within the putative promoter region of the cGnRH-II gene: initiators (Inr) (Smale \& Baltimore 1989) at positions +15 to +21 and -42 to -37 , and downstream promoter elements (DPE) (Burke \& Kadonaga 1996) at positions +34 to +39 and -12 to -7 . Two complementary experimental approaches, primer extension and RPA, were undertaken to determine if the transcription start site of the cGnRH-II gene was located among these sequence elements in the promoter of the striped bass cGnRH-II gene.

Primer extension assays were performed on striped bass brain mRNA using two synthetic oligomers, $\mathrm{C} 2$ and $\mathrm{C} 3$, to determine the precise start site within this region (Fig. 3). In general, the primer extension results with both oligomers consistently produced multiple bands and a high background, thus making the analysis difficult (data not shown). Positive controls using identical oligomers on sense RNA transcribed in vitro from gilthead seabream cGnRH-II cDNA produced a single band. Four transcription initiation sites were identified despite the high background and have been reproduced. The oligo $\mathrm{C} 2$ produced four bands at positions $-27,-41,-110$ and -150 
A)

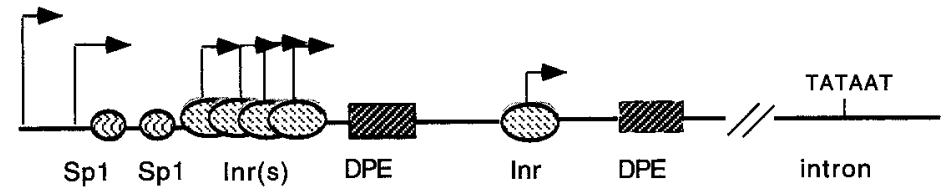

B)

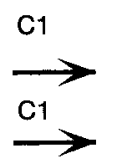

(Probe 1)

(Probe 2)

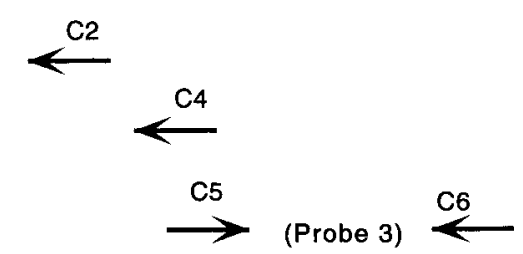

FIGURE 4. Schematic representation of the promoter region of the cGnRH-II gene in striped bass. (A) Illustrates the relative placement of putative sequence elements which may be involved in directing transcription of the gene. (B) Illustrates roughly the design of probes used in RPAs to map the transcription start sites in the cGnRH-II gene. The probes were generated by PCR using the primers detailed in the figure. Probes 1 and 2 were designed to encompass a region in the $5^{\prime}$ portion of the gene that shows significant nucleotide sequence identity to the $5^{\prime}$ UTR of the gilthead seabream cGnRH-II cDNA. Both probes are delineated at their $5^{\prime}$ end by primer C1, approximately $250 \mathrm{bp}$ upstream from this region of sequence identity. Probe 1 is delineated at the $3^{\prime}$ end by primer $\mathrm{C} 2$, approximately $14 \mathrm{bp}$ upstream from a putative intron/exon splice junction. Probe 2 is delineated at its $3^{\prime}$ end by primer $\mathrm{C} 4$, which lies downstream from the putative splice junction. Probe 3 , generated using primers C5 and C6, encompasses a region within the first intron of the gene that contains a canonical TATA box and transcription initiation sequence.

relative to the putative major start site. The oligo C3 validated only the -110 initiation site.

To verify the primer extension assay results, an RPA was designed using three separate probes directed at the putative $5^{\prime}$ UTR of the cGnRH-II gene. These probes were generated by PCR using primers with the cGnRH-II genomic clone (see Fig. 4 for details of probe design). Results from this RPA using probes 1 and 2 confirmed that multiple start sites are indeed present in the candidate region tested. A typical example of the RPA results is shown in Fig. 5 and Fig. 3 summarizes the RPA and the primer extension data. The transcriptional start sites predominate within a window of approximately 100 bases and most are clustered into three groups of multiple, overlapping sites.

Interestingly, sequence analysis identified a canonical TATAAT box and transcription initiation sequence within the first intron of the cGnRH-II gene, and therefore one of the RPA probes was designed to determine if this region of the gene was present in mRNA transcripts. There were no protected fragments visible with probe 3 , indicating that the putative TATA box promoter identified within the first intron is not active within the brains of sexually mature striped bass. This is consistent with data obtained from PCR analysis of the cDNA generated from these brains (data not shown). No amplified product was obtained using primers encompassing the first intron.

\section{Identification of putative regulatory elements in the striped bass cGnRH-II gene}

The striped bass cGnRH-II gene lacks any of the reproductively relevant steroid binding sites that have been previously implicated in the functional regulation of $\mathrm{GnRH}$ gene expression. Comparative analysis between the promoter regions of the striped bass sbGnRH and the cGnRH-II genes reveals that the putative DNA binding elements identified for each $\mathrm{GnRH}$ are quite distinct. The only potential steroid hormone binding domains common to both GnRH gene promoters are ERE-like motifs. A region has been identified within the cGnRH-II promoter at position -2599 to -2606 which is 


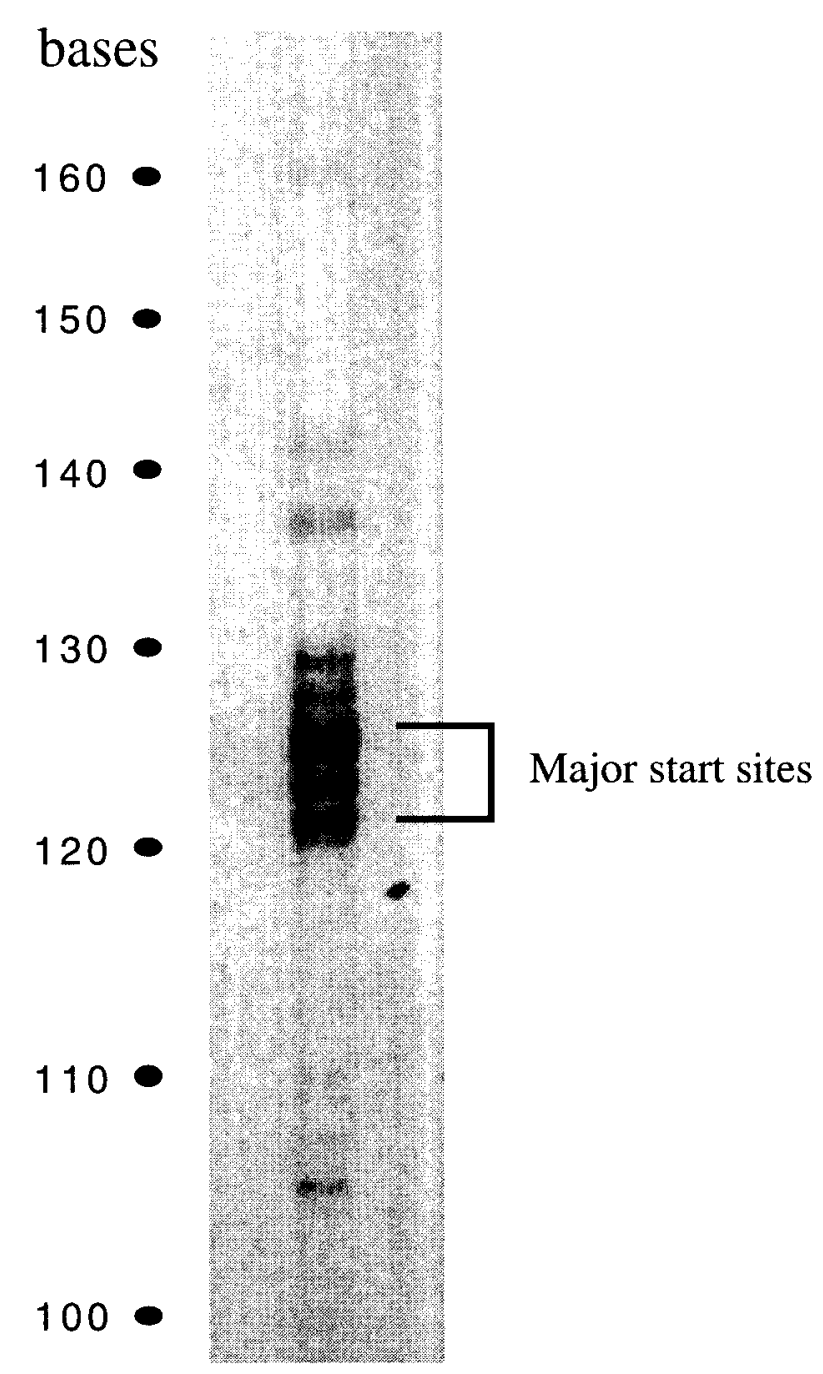

FIGURE 5. RPA results. Thirty micrograms poly $\left(\mathrm{A}^{+}\right)$ mRNA from striped bass brains were hybridized with one of three probes designed to encompass the putative 5' UTR of the cGnRH-II gene. Results from probe 2 are shown. Protected fragments of various sizes indicate multiple transcription start sites in the $5^{\prime}$ region of the cGnRH-II gene.

identical to a site previously shown to bind Oct-1 within the enhancer region of the rat $\mathrm{mGnRH}$ promoter (Clark \& Mellon 1995). Consensus binding sequences for other members of the POU-domain family of DNA binding factors have been identified in the cGnRH-II promoter: Brn-2 at -1350 to -1366 and -1228 to -1241 , and Pit-1 at -1317 to -1325 . Canonical CRE and AP-1 binding site sequences were also identified at positions -843 to -837 and -590 to -596 respectively.

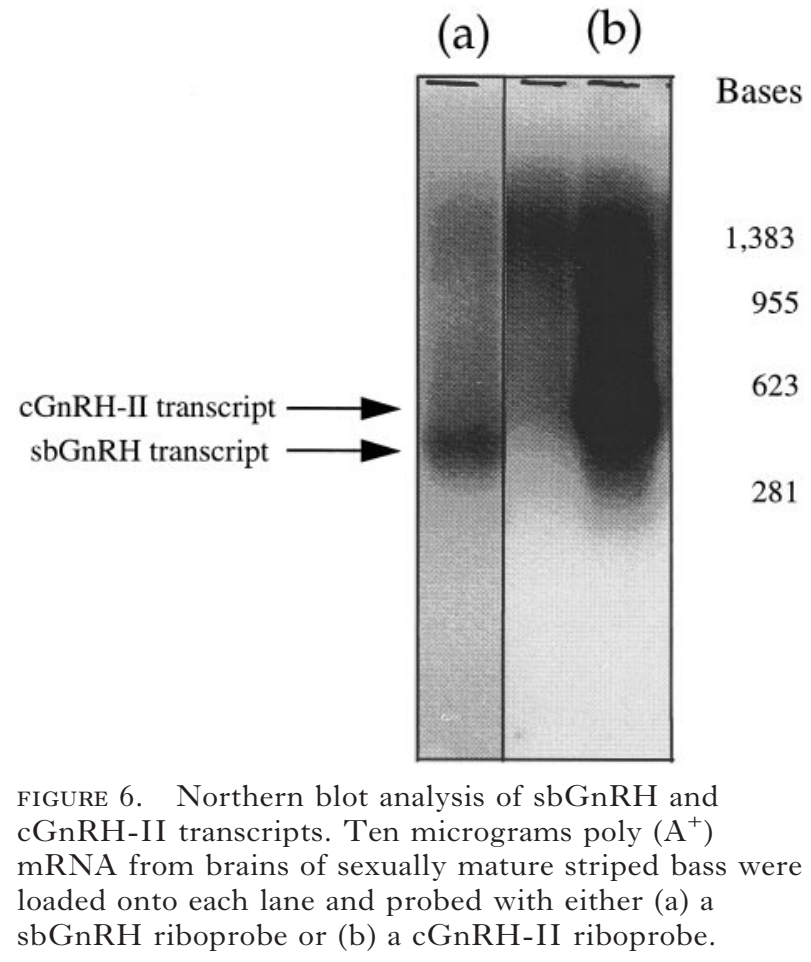

\section{Northern blot analysis of GnRH in sexually mature striped bass brains}

Poly $\left(\mathrm{A}^{+}\right)$mRNA $(10 \mu \mathrm{g})$ isolated from the brains of sexually mature striped bass was hybridized with single-stranded RNA probes corresponding to partial cDNA sequences from the striped bass sbGnRH or the striped bass cGnRH-II. The Northern blot results (Fig. 6) indicate that both the sbGnRH and the cGnRH-II genes are active in the brains of fully developed striped bass, since levels of both transcripts are easily detectable. The transcript sizes obtained from the Northern blot analyses for both the sbGnRH and the cGnRH-II mRNAs are consistent with the sizes calculated from the predicted precursor length (originating at +1 , the empirically derived start site, and ending at the first polyadenylation site), which are $357 \mathrm{bp}$ for the sbGnRH precursor and $620 \mathrm{bp}$ for the cGnRH-II precursor.

\section{DISCUSSION}

Striped bass are members of the order Perciformes, which comprises the largest and most rapidly radiated group of teleost fish. To date, perciform fish remain the only vertebrate order for which three forms of GnRH have been isolated and 
characterized at the level of the peptide (Powell et al. 1994) and cDNA (Gothilf et al. 1995, 1996b) and for which the brain localization of all three forms has been determined (White et al. 1995, Gothilf et al. 1996b). For these reasons, perciform fish currently represent an excellent model system available to study the biological significance of multiple forms of $\mathrm{GnRH}$ within a single vertebrate species. It is important to note that there is growing evidence to indicate that multiple forms of $\mathrm{GnRH}$ will not be limited to perciform fish. Both HPLC and immunocytochemical studies have demonstrated that multiple forms of $\mathrm{GnRH}$ are present in non-perciform fish (Scorpaeniformes (Powell et al. 1996) and Characiformes (Somoza et al. 1994, Powell et al. 1997)), amphibians (Conlon et al. 1993, Iela et al. 1996), reptiles (Negrin \& Bello 1996), birds (Norgren \& Gao 1994) and even mammals (Lescheid et al. 1997). This recent discovery, that primate brains contain three forms of $\mathrm{GnRH}$ (mammalian GnRH (mGnRH), cGnRH-II and an unidentified GnRH form), clearly suggests that the presence of multiple forms of $\mathrm{GnRH}$ is likely to be prevalent in most, if not all, vertebrate species. Taken together, these findings raise an important question - if the presence of multiple forms of $\mathrm{GnRH}$ is to be considered the rule rather than the exception, what are the different roles multiple members of the GnRH family contribute to reproductive competence? One approach towards answering this question is to identify the factors which may be involved in the differential regulation of the GnRH genes present in a single vertebrate species. In order to initiate these studies, we have isolated and characterized two of the three GnRH genes present in a teleost fish, the striped bass.

The genomic organization of the striped bass sbGnRH and cGnRH-II genes, each comprising four exons and three introns, is identical to that reported for all GnRH genes, suggesting that the overall structure of $\mathrm{GnRH}$ genes is conserved. The most highly conserved region of all $\mathrm{GnRH}$ genes lies within exon II and encodes the GnRH decapeptide, which is the bioactive domain of the GnRH precursor. Phylogenetic maps of amino acid changes within the decapeptide have been constructed to recapitulate the evolution of the $\mathrm{GnRH}$ family from ancient (Agnatha) to more recently evolved vertebrates (mammals) and are in accordance with the fossil record (Sherwood et al. 1997). In contrast, the GAP, a region of the $\mathrm{GnRH}$ gene whose function has yet to be established (Nikolics et al. 1985, Millar et al. 1986, Yu et al. 1989), is encoded primarily by exons III and IV in all GnRH genes and exhibits very little sequence conservation between species, the exception being the small portion of the GAP ( $\sim 20 \%$ ) which falls within exon II (Table 2). Overall, exon II remains the most conserved region of the GnRH gene, an indication of the strong evolutionary pressure to maintain and conserve the most physiologically relevant unit of the GnRH gene.

A major focus of this study was to identify candidate DNA elements which may be involved in the coordinated regulation of $\mathrm{GnRH}$ gene expression. The identification of AP-1 binding sites in sbGnRH and cGnRH-II is interesting in that these sites have also been found in the sGnRH promoter regions of Atlantic and Pacific salmon. The discovery of an SF-1 DNA binding domain in the promoter of the striped bass sbGnRH raises the intriguing possibility that SF-1 may regulate sbGnRH gene expression. Although SF-1 has not yet been implicated in the regulation of $\mathrm{GnRH}$, this transcription factor, which is an orphan steroid receptor (Lala et al. 1995), is an essential regulator of other reproduction-related genes, such as gonadotropins and the $\mathrm{GnRH}$ receptor (Barnhart \& Mellon 1994, Ingraham et al. 1994). It is therefore possible that a potential ligand of this orphan receptor might play a role in the coordinated regulation of reproduction-related genes in different tissues.

The presence of a GRE motif located in the upstream region ( -2861 to -2847$)$ of the sbGnRH gene suggests that the glucocorticoid receptor (GR) may influence $\mathrm{GnRH}$ synthesis, possibly via direct action on the GnRH neurons, and thereby may significantly affect the reproductive axis. Numerous studies have established a correlation between chronic stress, elevated plasma glucocorticoids and reduced reproductive function in vertebrates. Studies using female rats had previously suggested that the effects of glucocorticoids on GnRH are exerted at a hypothalamic site (Brann \& Mahesh 1991) and this has since been supported by the immunolocalization of GRs to GnRH neurons in the rat brain (Ahima \& Harlan 1992). The transformed GT-1 mammalian hypothalamic cell line has been shown to contain functional GRs which mediate the action of glucocorticoids by downregulating the expression of the endogenous $\mathrm{GnRH}$ gene and also repress transcription of transfected rat and $\mathrm{mGnRH}$ promoters (Chandran et al. 1994). Similarly, GRs were recently localized by both immunocytochemistry and in situ hybridization to regions of the rainbow trout brain known to contain GnRH neurons (C Teitsma, B Ducouret \& O Kah, personal communication). It is reasonable to speculate that during times of stress, elevated levels of glucocorticoids play a negative regulatory role in the reproductive axis by acting directly on 
GnRH neurons to inhibit GnRH gene expression in both fish and mammals. If glucocorticoids are, in fact, acting on genomic sites within the hypothalamus to inhibit reproduction in vertebrates, the logical target is the most reproductively relevant form of GnRH, which, in striped bass, is the sbGnRH gene.

The presence of EREs within the sbGnRH promoter raises the tempting speculation that sbGnRH synthesis is regulated by estrogen. However, across mammals (Shivers et al. 1983, Herbison et al. 1993, Sullivan et al. 1995) and in one fish (Navas et al. 1995), it has been shown that GnRH-producing neurons do not contain estrogen receptors. It is therefore not likely that estrogen will have a direct effect on GnRH expression in the hypothalamus.

The identification of the POU-domain binding elements (Oct-1, Pit-1 and Brn-2) in the cGnRH-II promoter is of interest in that Pit-1 and Oct-1 have been shown to be widely expressed during the development of the central nervous system (Treacy \& Rosenfeld 1992). Oct-1 has also been shown to bind the enhancer region of luteinizing hormone-releasing hormone gene (Clark \& Mellon 1995). Brn-2 has been shown to be necessary for development and maintenance of the embryonic hypothalamus in mice (Nakai et al. 1995, Schonemann et al. 1995), and has recently been identified in GT1 hypothalamic cells using RT-PCR (Clark \& Mellon 1995). The spatial and temporal regulation of the cGnRH-II gene during development has not yet been studied, but these results suggest that the POU-domain family of transcription factors may be involved. It remains to be demonstrated whether the DNA regulatory elements revealed in this study are involved in the transcriptional control of the sbGnRH and the cGnRH-II genes. Further studies are needed to test and clarify their functional significance.

The location of the sbGnRH transcription start site was readily predicted, based largely on its proximal distance to the TATA box promoter. As expected, its position was confirmed via RT-PCR.

Primer extension and RPAs have provided evidence for multiple transcription start sites for the cGnRH-II gene in striped bass, typical of genes which lack a canonical TATA-box promoter. Two groups of clustered start sites are centered around elements shown to be sufficient to support transcription in the absence of a TATA box, an Inr and a DPE. One of these initiation sites revealed by the RPA is centered at +18 and contains at least four start sites. This site contains four overlapping Inr-like elements which are most likely involved in transcriptional activation of this region (Fig. 3).
Despite the abundance of protected fragments, the relative intensities of the bands shown in Fig. 5 reveal that the most active sites of transcription initiation are concentrated within a 10 -base region centered about position +1 . Although this region lacks homology to any known Inr sequence, a weak TATA box (TATATT) is present 25 bases upstream from these initiation sites and two putative SP-1 binding sites are located upstream from the TATATT sequence.

An unexpected outcome of the sequence analysis of the GnRH genes was the discovery that the cGnRH-II gene may have multiple promoters. Whereas the upstream promoter region lacks a consensus TATA box, a canonical TATA box is located within the first intron, although the functionality of the TATA box promoter has yet to be demonstrated. All of our experimental results described in this paper demonstrate that the TATA-deficient promoter is preferentially utilized in the sexually mature striped bass brain.

By comparison, all of the GnRH genes characterized to date have a conventional promoter, in that a consensus TATA box lies within the constrained 25 bases upstream of the transcriptional start site. However, the human $\mathrm{mGnRH}$ gene contains an additional upstream start site which lacks a TATA box and has been demonstrated to be active in non-hypothalamic reproductive tissues, such as ovary, testis, placenta, and mammary gland (Dong et al. 1993). There has been no reported evidence for the presence of additional promoters or upstream transcriptional start sites for the rat or mouse mGnRH genes. Despite the report that the Atlantic salmon sGnRH gene has two promoters, there have been no published reports indicating that the distal promoter is active. Whether the cGnRH-II has two functional promoters that are differentially regulated is unknown. Since the promoter analysis described in this work was limited to brains of sexually mature fish, it remains a possibility that the putative TATA box promoter identified within the first intron is active in different tissues and/or at different stages of development. Understanding the expression pattern of the cGnRH-II gene will be fundamental to elucidating its function in vertebrates.

In summary, when the sbGnRH and the cGnRH-II gene promoters are compared with the promoter regions of other $\mathrm{GnRH}$ genes there are some surprising similarities and a few striking differences. The GnRH gene family is a remarkable example of how promoter regions are capable of undergoing relatively rapid changes while conserving the structural components of a gene, allowing for selective adaptations to occur in a constantly 
changing environment. In this manner, GnRH may have been recruited throughout its evolution to play multiple roles within the complex physiology of reproduction and possibly other systems.

\section{ACKNOWLEDGEMENTS}

This work was supported by funding to $\mathrm{Y} \mathrm{Z}$ from the Maryland Sea Grant Program (award \#NA46RG0091) and the Maryland Agricultural Experimental Station (award \#AQUA-97-09). This is contribution \#314 from the Center of Marine Biotechnology, University of Maryland Biotechnology Institute. The nucleotide sequences reported in this work have been deposited in GenBank. The accession numbers for the cGnRH-II and sbGnRH gene sequences from Morone saxatilis are AFO56313 and AFO56314 respectively.

\section{REFERENCES}

Ahima RS \& Harlan RE 1992 Glucocorticoid receptors in LHRH neurons. Neuroendocrinology 56 845-850.

Amos MR, Burgus R, Blackwell R, Vale W, Fellows R \& Guillemin R 1971 Purification, amino acid composition and $\mathrm{N}$-terminus of the hypothalamic luteinizing hormone releasing factor (LRF) of ovine origin. Biochemical and Biophysical Research Communications 44 205-210.

Barnhart KM \& Mellon PL 1994 The orphan nuclear receptor, steroidogenic factor-1, regulates the glycoprotein hormone alpha-subunit gene in pituitary gonadotropes. Molecular Endocrinology 8 878-885.

Beato M 1989 Gene regulation by steroid hormones. Cell $\mathbf{5 6}$ 335-344.

Bogerd JT, Zandbergen MA, Andersson E \& Goos HJTh 1994 Isolation, characterization and expression of cDNAs encoding the catfish-type and chicken-II-type gonadotropinhormone-releasing-hormone precursors in the African catfish. European Fournal of Biochemistry 222 541-549.

Brann DW \& Mahesh VB 1991 Detailed examination of the mechanism and site of action of progesterone and corticosteroids in the regulation of gonadotropin secretion: hypothalamic gonadotropin releasing hormone and catecholamine involvement. Biology of Reproduction $\mathbf{4 4}$ 1005-1015.

Burke TW \& Kadonaga JT 1996 Drosophila TFIID binds to a conserved basal promoter element that is present in many TATA-box-deficient promoters. Genes and Development 10 711-724.

Chandran UR, Attardi B, Friedman R, Dong KW, Roberts JL \& DeFranco DB 1994 Glucocorticoid receptor-mediated repression of gonadotropin-releasing-hormone promoter activity in GT1 hypothalamic cell lines. Endocrinology 134 1467-1474.

Clark ME \& Mellon PL 1995 The POU homeodomain transcription factor Oct-1 is essential for activity of the gonadotropin-releasing-hormone neuron-specific enhancer. Molecular and Cellular Biology 15 6169-6177.

Coe IR, von Schalburg KR \& Sherwood NM 1995 Characterization of the Pacific salmon gonadotropinreleasing-hormone gene, copy number and transcriptional start site. Molecular and Cellular Endocrinology 115 113-122.

Conlon JM, Collin F, Chiang YC, Sower SA \& Vaudry H 1993 Two molecular forms of gonadotropin-releasing-hormone from the brain of a frog, Rana fidibunda: purification, characterization and distribution. Endocrinology 132 $2117-2123$.

Cummings SA \& Thorgaard GH 1994 Extraction of DNA from fish blood and sperm. Biotechniques 17426.

Dong KW, Yu KL \& Roberts JL 1993 Identification of a major upstream transcriptional start site for the human progonadotropin-releasing hormone gene used in reproductive tissues and cell lines. Molecular Endocrinology 7 1654-1666.

Francis RCF, Soma K \& Fernald RD 1993 Social regulation of the brain-pituitary-gonadal axis. Proceedings of the National Academy of Sciences of the USA 90 7794-7798.

Gothilf Y, Elizur A, Chow M, Chen TT \& Zohar Y 1995 Molecular cloning and characterization of a novel gonadotropin-releasing hormone from the gilthead seabream (Sparus aurata). Molecular Marine Biology and Biotechnology $427-35$.

Gothilf Y, Elizur A, Powell JFF, Sherwood NM \& Zohar Y $1996 a$ Three forms of gonadotropin-releasing hormone in gilthead seabream and striped bass: physiological and molecular studies. Proceedings of the Fifth International Symposium on the Reproductive Physiology of Fish, pp 52-54. Eds FW Goetz \& P Thomas. Austin: Fish Symposium 1995.

Gothilf Y, Munoz-Cueto JA, Sagrillo CA, Selmanoff M, Chen TT, Kah O, Elizur A \& Zohar Y $1996 b$ Three forms of gonadotropin-releasing hormone in a perciform fish (Sparus aurata): complementary deoxyribonucleic acid characterization and brain localization. Biology of Reproduction 55 636-645.

Gothilf Y, Meiri I, Elizur A \& Zohar Y 1997 Changes in mRNA levels of the three GnRH forms during final oocyte maturation, ovulation and spawning in the gilthead seabream, Sparus aurata. Biology of Reproduction $\mathbf{5 7}$ 1145-1154.

Herbison AE, Robinson JF \& Skinner DC 1993 Distribution of estrogen receptor-immunoreactive cells in the preoptic area of the ewe: co-localization with glutamic acid decarboxylase but not luteinizing hormone releasing hormone. Neuroendocrinology $\mathbf{5 7} 751-759$.

Iela L, Powell JFF, Sherwood NM, D'Aniello B, Rastogi RK \& Bagnara JT 1996 Reproduction in the Mexican leaf frog, Pachymedusa dacnicolor VI: presence and distribution of multiple GnRH forms in the brain. General and Comparative Endocrinology 103 235-243.

Ingraham HA, Lala DS, Ikeda Y, Luo X, Shen WH, Nachtigal MW, Abbud R, Nilson JH \& Parker KL 1994 The nuclear receptor steroidogenic factor 1 acts at multiple levels of the reproductive axis. Genes and Development $\mathbf{8}$ 2302-2312.

Kasten TL, White SA, Norton TT, Bond CT, Adelman JP \& Fernald RD 1996 Characterization of two new preproGnRH mRNAs in the tree shrew: first direct evidence for mesencephalic GnRH gene expression in a placental mammal. General and Comparative Endocrinology 104 7-19.

Kepa JK, Jacobsen BM, Boen EA, Pendergast P, Edwards DP, Takimoto G \& Wierman ME 1996 Direct binding of progesterone receptor to nonconsensus DNA sequences represses rat GnRH. Molecular and Cellular Endocrinology $11727-39$.

King JA \& Millar RP 1991 Gonadotropin-releasing hormones. In Vertebrate Endocrinology: Fundamentals and Biomedical Implications, part IV, pp 1-31. Eds PKT Pang \& MP Schreibman. New York: Academic Press. 
Klungland $\mathrm{H}$, Andersen $\mathrm{O}$, Kisen G, Alestrom P \& Tora L 1993 Estrogen receptor binds to the salmon GnRH gene in a region with long palindromic sequences. Molecular and Cellular Endocrinology 95 147-154.

Lala DS, Ikeda Y, Luo X, Baity LA, Meade JC \& Parker KL 1995 A cell-specific nuclear receptor regulates the steroid hydroxylases. Steroids 60 10-14.

Lescheid DW, Terasawa E, Abler L, Urbansky HF, Warby CM, Millar RP \& Sherwood NM 1997 A second form of gonadotropin-releasing hormone $(\mathrm{GnRH})$ in the primate brain. Endocrinology 138 5618-5629.

Lin X \& Peter RE 1996 Expression of salmon gonadotropinreleasing hormone $(\mathrm{GnRH})$ and chicken GnRH-II messenger ribonucleic acids in the brain and ovary of goldfish. General and Comparative Endocrinology 101 282-296.

Matsuo H, Baba Y, Nair R, Arimura A \& Schally A 1971 Structure of the porcine LH and FSH-releasing hormone. Biochemical and Biophysical Research Communications $\mathbf{4 3}$ 1334-1339.

Millar RP, Milton R, Follet B \& King JA 1986 Receptor binding and gonadotropin-releasing activity of a novel chicken gonadotropin-releasing hormone ([His5Trp7Tyr8] GnRH) and D-Arg6 analog. Endocrinology 119 224-231.

Muske LE 1993 Evolution of gonadotropin-releasing hormone (GnRH) neuronal systems. Brain and Behavioral Evolution 42 215-230.

Nakai S, Kawano H, Yudate T, Nishi M, Kuno J, Nagata A, Jishage K, Hamada H, Fujii H, Kawamura K, Shiba K \& Noda T 1995 The POU domain transcription factor Brn-2 is required for the determination of specific neuronal lineages in the hypothalamus of the mouse. Genes and Development 9 3109-3121.

Navas JM, Anglade I, Bailhache T, Pakdel F, Breton B, Jego P \& Kah O 1995 Do gonadotropin-releasing hormone neurons express estrogen receptors in the rainbow trout? A double immunohistochemical study. Fournal of Comparative Neurology 362 1-14.

Negrin I \& Bello AR 1996 Immunocytochemical localization of three forms of gonadotropin-releasing hormones in the brain of lizard, Gallotia galloti. In $18^{\text {th }}$ Conference of European Comparative Endocrinologists: from Molecular to Integrative Biology. Annales d'Endocrinologie 57 (4) 34.

Nikolics K, Mason A, Szonyi E, Ramachandran J \& Seeburg P 1985 A prolactin-inhibiting factor within the precursor for human gonadotropin-releasing hormone. Nature $\mathbf{3 1 6}$ $511-517$.

Norgren RB \& Gao C 1994 LHRH neuronal subtypes have multiple origins in chickens. Developmental Biology 165 $735-738$.

Okuzawa K, Araki K, Tanaka H, Kagawa H \& Hirose K 1994 Molecular cloning of a cDNA encoding the preprosalmon gonadotropin-releasing hormone of the red seabream. General and Comparative Endocrinology 96 234-242.

Okuzawa K, Granneman J, Bogerd JT, Goos HJTh, Zohar Y \& Kagawa H 1997 Distinct expression of GnRH genes in the red seabream brain. Fish Physiology and Biochemistry 17 71-79.

Powell JFF, Zohar Y, Elizur A, Park M, Fischer WH, Craig AG, Rivier JE, Lovejoy DA \& Sherwood NM 1994 Three forms of gonadotropin-releasing hormone characterized from the brain of one species. Proceedings of the National Academy of Sciences of the USA 91 12081-12085.

Powell JFF, Krueckl SL, Collins PM \& Sherwood NM 1996 Molecular forms of $\mathrm{GnRH}$ in three model fishes: rockfish, medaka and zebrafish. Fournal of Endocrinology 150 $17-23$.

Powell JFF, Standen EM, Carolsfeld J, Borella MI, Gazola R, Fischer WH, Park M, Craig AG, Warby CM, Rivier JE, Val Sella MV \& Sherwood NM 1997 Primary structure of three forms of gonadotropin-releasing hormone $(\mathrm{GnRH})$ from the pacu brain. Regulatory Peptides 68 189-195.

Rice DA, Kirkman MS, Aitken LD, Mouw AR, Schimmer BP \& Parker KL 1990 Analysis of the promoter region of the gene encoding mouse cholesterol side-chain cleavage enzyme. Fournal of Biological Chemistry 265 11713-11720.

Roesler WJ, Vandenbark GR \& Hanson RW 1988 Cyclic AMP and the induction of eukaryotic gene transcription. Fournal of Biological Chemistry 263 9063-9066.

Schonemann M, Ryan A, McEvilly R, O'Connell S, Arias C, Kalla K, Li P, Sawchenko P \& Rosenfeld M 1995 Development and survival of the endocrine hypothalamus and posterior pituitary gland requires the neuronal POU domain factor Brn-2. Genes and Development 9 3122-3135.

Sherwood NM, Parker DB, McRory JE \& Lescheid DW 1994 Molecular evolution of growth hormone-releasing hormone and gonadotropin-releasing hormone. In Molecular Endocrinology of Fish: Fish Physiology, vol XII, pp 3-66. Eds AP Farrell \& DJ Randall. San Diego: Academic Press.

Sherwood NM, von Schalburg K \& Lescheid DW 1997 Origin and evolution of $\mathrm{GnRH}$ in vertebrates and invertebrates. In GnRH Neurons: From Genes to Behavior, pp 3-25. Eds IS Parhar \& Y Sakuma. Tokyo: Brain Shuppan.

Shivers BD, Harlan RE, Morrell JI \& Pfaff DW 1983 Absence of estradiol concentration in nuclei of LHRH immunoreactive neurons. Nature 304 345-347.

Smale ST \& Baltimore D 1989 The 'initiator' as a transcriptional control element. Cell 57 103-113.

Somoza GM, Stefano A, D'Eramo JL, Canosa LF \& Fridman O 1994 Immunoreactive GnRH suggesting a third form of GnRH in addition to cGnRH-II and sGnRH in the brain and pituitary gland of Prochilodus lineatus (Characiformes). General and Comparative Endocrinology 94 44-52.

Sullivan KA, Witkin JW, Ferin M \& Silverman AJ 1995 Gonadotropin-releasing hormone neurons in the rhesus macaque are not immunoreactive for the estrogen receptor. Brain Research 685 198-200.

Treacy MN \& Rosenfeld MG 1992 Expression of a family of POU-domain protein regulatory genes during development of the central nervous system. Annual Review of Neurosciences 15 139-165.

Weber G, Powell JFF, Park M, Fischer WH, Craig AG, Rivier JE, Nanakorn U, Parhar IS, Grau EG \& Sherwood NM 1997 Evidence that gonadotropin-releasing hormone (GnRH) functions as a prolactin-releasing factor in a teleost fish (Oreochromis mossambicus) and primary structures for three native GnRH molecules. Fournal of Endocrinology 132 2360-2370.

White SA, Kasten TL, Bond CT, Adelman JP \& Fernald RD 1995 Three gonadotropin-releasing hormone genes in one organism suggest novel roles for an ancient peptide. Proceedings of the National Academy of Sciences of the USA 92 8363-8367.

Yu K, Peng C \& Peter RE 1989 Changes in the brain levels of gonadotropin-releasing hormone and serum levels of gonadotropin and growth hormone in goldfish during spawning. Canadian Fournal of Zoology 69 182-188.

REVISED MANUSCRIPT RECEIVED 10 May 1998 